\title{
The role of selected Auchenorrhyncha species (Hemiptera: Cicadomorpha \& Fulgoromorpha) in a transmission of 'Candidatus Phytoplasma asteris' phytoplasma - a causal factor of oilseed rape phyllody
}

\author{
Rola wybranych gatunków piewików (Hemiptera: Cicadomorpha \\ \& Fulgoromorpha) w przenoszeniu fitoplazmy 'Candidatus Phytoplasma \\ asteris' - sprawcy fyllodiozy rzepaku
}

\author{
Agnieszka Zwolińska ${ }^{1}$, Tomasz Klejdysz ${ }^{1}$, Krzysztof Krawczyk $^{1}$, Jan Nawrot ${ }^{2}$
}

\begin{abstract}
Summary
Phytoplasma that belongs to the aster yellows (AY), 16Srl-B subgroup and causes characteristic deformations of winter oilseed rape plants (Brassica napus) has been observed in Poland more then a decade. The diseased plants exhibit phyllody of flowers, which lead to siliques malformations and losses in seed production. The aim of this study was to find a natural insect vector of AY involved in epidemiology of oilseed rape phyllody disease in Poland. Two species: Macrosteles laevis and Psammotettix alienus were selected as potential vectors and adult leafhoppers of these species were placed in cages with phytoplasma infected oilseed rape. After acquisition period, individuals of each species were transferred to cages containing healthy seedlings of test plants: summer and winter oilseed rape (B. napus), barley (Hordeum vulgare), Madagascar periwinkle (Catharantus roseus) and broad bean (Vicia faba). After inoculation, the insects were examined for phytoplasma presence in their tissue by sequencing PCR (polymerase chain reaction) products. Only $M$. laevis leafhoppers tested positive. The test plants were analyzed in the same manner. The disease agent was transmitted by the $M$. laevis, to barley, periwinkle and broad bean, but not to oilseed rape.
\end{abstract}

Key words: phytoplasma; vectors; oilseed rape; phyllody; transmission; leafhoppers

\section{Streszczenie}

Fitoplazmy należące do grupy żółtaczek astra (AY - aster yellows), podgrupy 16Srl-B powodują charakterystyczne deformacje rzepaku ozimego (Brassica napus) w uprawach w Polsce od ponad dekady. Porażone rośliny wykształcają w miejsce kwiatów tzw. fyllodia, które prowadzą do deformacji łuszczyn i strat w produkcji nasion. Celem pracy było rozpoznanie naturalnego wektora fitoplazmy wywołującej chorobę rzepaku zwaną fyllodiozą. Zbadano potencjał przenoszenia fitoplazmy infekującej rzepak przez dwa gatunki skoczków: Macrosteles laevis i Psammotettix alienus. Na zainfekowanej fitoplazmą AY 16Srl-B roślinie rzepaku hodowano zdrowe owady, a następnie osobniki obu gatunków przenoszono na siewki zdrowych roślin rzepaku jarego i ozimego, jęczmienia, katarantusa różowego oraz bobu. Po zakończeniu inokulacji, owady testowano pod kątem obecności fitoplazmy w ich tkankach, sekwencjonując produkty reakcji PCR (polymerase chain reaction). W przeprowadzonych testach tylko owad $M$. laevis nabywał fitoplazmę. Zakażane rośliny po okresie obserwacji testowano w analogiczny sposób, jak owady. Uzyskano przeniesienie fitoplazmy wywołującej fyllodiozę rzepaku przez $M$. laevis na rośliny testowe: jęczmień, bób i katarantusa, ale nie potwierdzono przenoszenia fitoplazmy na rzepak.

Słowa kluczowe: fitoplazma; wektor; rzepak; fyllodia; przenoszenie; skoczki

\footnotetext{
Instytut Ochrony Roślin - Państwowy Instytut Badawczy

Władysława Węgorka 20, 60-318 Poznań

${ }^{2}$ Emerytowany Profesor Instytutu Ochrony Roślin - Państwowego Instytutu Badawczego

*corresponding author: a.zwolinska@iorpib.poznan.pl
} 


\section{Wstęp / Introduction}

Fitoplazmy są drobnymi, patogenicznymi bakteriami żyjącymi wewnątrzkomórkowo w łyku roślin. Występują na całym świecie, ale największe straty powodują w ciepłych rejonach globu, w uprawach winorośli, trzciny cukrowej oraz palmy kokosowej (Bertaccini i wsp. 2014). Łącznie znanych jest około 700 chorób roślin o podłożu fitoplazmatycznym. Do objawów wywoływanych przez fitoplazmy należą: żółknięcie lub czerwienienie liści, skracanie międzywęźli prowadzące do skarłowaciałego pokroju roślin, zmniejszanie wielkości liści, nadmierny rozrost pędów bocznych prowadzący do formowania się tzw. czarcich mioteł, fyllodia - liściaste struktury w miejscu kwiatów, nekrozy łyka, a także zamieranie i śmierć roślin (McCoy i wsp. 1989; Lee i wsp. 2000). Fitoplazmy przenoszone są między roślinami przez owady $\mathrm{z}$ rzędu pluskwiaków (Hemiptera), głównie przedstawicieli rodziny skoczków (Cicadellidae) należącej do podrzędu piewików (Cicadomorpha) oraz rodziny miodówek (Psyllidae) należącej do podrzędu piersiodziobych (Sternorrhyncha) (Ploaie 1981). Podczas żerowania na porażonej roślinie owad będący wektorem pobiera fitoplazmy, które pokonują ścianę jego jelita i namnażają się w hemolimfie, by ostatecznie trafić do ślinianek. Na tym etapie, zakażony owad może wprowadzić komórki fitoplazmy wraz ze śliną do komórek nowego gospodarza roślinnego, podczas kolejnego żerowania (Weintraub i Beanland 2006). Okres od momentu nabycia do momentu zdolności przekazania patogenu na nową roślinę żywicielską nazywa się okresem latencji i trwa on zazwyczaj 2-4 tygodnie (Brčák 1979). W określonym środowisku fitoplazmy mają specyficznego wektora, który odpowiada za ich rozprzestrzenianie się (Schultz 1973; Maixner i wsp. 1995; Gatineau i wsp. 2001).

Fitoplazma 'Candidatus Phytoplasma asteris' jest znana jako czynnik sprawczy żółtaczki astra (AY - aster yellows), ale poraża około 300 gatunków roślin, w tym wiele roślin uprawnych, takich jak: kukurydza i rzepak (Ebbert i wsp. 2001; Salehi i wsp. 2011), warzywnych m.in. marchew, sałatę i seler (Lee i wsp. 2004; Zhang i wsp. 2004; Fránová i Špak 2013), czy roślin ozdobnych (Sichani i wsp. 2014). Podgrupa 16SrI-B żółtaczki astra wywołuje fitoplazmatyczną chorobę rzepaku (Brassica napus) zwaną fyllodiozą rzepaku (RP - rapeseed phyllody) (Zwolińska i wsp. 2011a, b). W Polsce, rokrocznie obserwuje się na polach, występujące pojedynczo, charakterystyczne deformacje roślin rzepaku ozimego. Porażone rośliny charakteryzują się przekształceniem kwiatów w formy liściaste zwane fyllodiami, które prowadzą do sterylności roślin i strat $\mathrm{w}$ produkcji cennych nasion. Wektor fitoplazmy powodującej infekcję rzepaku ozimego nie został dotąd zidentyfikowany. Poznanie gatunku owada odpowiedzialnego za przenoszenie fyllodiozy rzepaku jest kluczowe dla epidemiologii choroby.

Za przenoszenie fitoplazmy żółtaczki astra typu I-B (grupa rybosomalna 16SrI-B) w innych częściach świata, odpowiedzialne są piewiki z rodzaju Macrosteles. W Japonii, fitoplazmy należące do grupy $16 \mathrm{SrI}-\mathrm{B}$ są przenoszone przez Macrosteles striifrons Anufriev (Okuda i wsp.
1997; Tanaka i wsp. 2007). W południowej i centralnej Europie Macrosteles quadripunctulatus Kirschbaum przenosi żółtaczkę chryzantemy (16SrI-B) na chryzantemy, cyklamen i winorośl (Bosco i wsp. 1997; Alma i wsp. 2000, 2001). Na kontynencie amerykańskim znanym wektorem żółtaczek astra, należących do dwóch szczepów AY 16SrI-B i AY 16SrI-A, jest skoczek Macrosteles quadrilineatus Forbes dawniej zwany Macrosteles fascifrons Stål (Maramorosch 1960; Tsai 1979). Wiadomym jest, iż obydwa szczepy porażają uprawy marchwi i rzepaku, i że są rozpowszechnione w owadach $M$. quadrilineatus (Lee i wsp. 1992, 2003; Olivier i wsp. 2011). Nie wiadomo jednak, czy właśnie ten gatunek owada odpowiedzialny jest za przenoszenie 'Candidatus Phytoplasma asteris' $\mathrm{z}$ podgrupy $16 \mathrm{SrI}-\mathrm{B}$ na rośliny rzepaku i marchwi.

Do najpopularniejszych gatunków piewików wchodzących w skład polskiej entomofauny terenów uprawnych należą: skoczek sześciorek Macrosteles laevis Ribaut, zgłobik smużkowany Psammotettix alienus Dahlbom, Hardya tenuis Germar, skoczek ziemniaczak Empoasca pteridis Dahlbom oraz na przypolnych terenach trawiastych: skoczek trawnik Javesella pellucida Fabricius (Klejdysz 2013). Spośród wymienionych gatunków skoczków: M. laevis, P. alienus i J. pellucida zostały opisane jako wektory fitoplazm wywołujących żółtaczki już w latach 60. XX wieku (Brčák 1979). W tamtym czasie diagnostyka fitoplazm oparta była o obserwację pod mikroskopem elektronowym komórek fitoplazm w ultracienkich skrawkach tkanek roślinnych i owadzich oraz porównywanie objawów. Brak jednak współczesnych, wiarygodnych opracowań dotyczących wektorów fitoplazm w środkowej i wschodniej części Europy. Jedyne prace prowadzone nad fitoplazmatyczną chorobą rzepaku pochodzą z 1971 roku (Lehman i Skadow 1971) i dowiodły możliwość przeniesienia fitoplazmy $\mathrm{z}$ naturalnie zainfekowanego rzepaku ozimego przez skoczka Euscelis incisus (Kirschbaum) na rośliny testowe: Trifolium repens, Chrysanthemum carinatum, Catharanthus roseus i Senecio vulgaris. W warunkach eksperymentalnych, przy użyciu tego samego wektora, udało się zakazić rzepak innym szczepem fitoplazmy - fyllodiozy koniczyny (clover phyllody) i uzyskać podobne objawy do tych powodowanych przez czynnik sprawczy fyllodiozy rzepaku (Lehman i Skadow 1971).

W niniejszej pracy zbadano potencjał przenoszenia fitoplazmy wywołującej fyllodiozę rzepaku przez dwa najpopularniejsze w Polsce gatunki skoczków (Cicadellidae): $M$. laevis i $P$. alienus. W jednym $\mathrm{z}$ wariantów doświadczenia użyto dodatkowo skoczków H. tenuis. Masowe testowanie owadów odławianych w rejonach pól porażonych fitoplazmą, na terenie stacji doświadczalnej w Winnej Górze oraz Borowie, w latach 2011-2013, wykazało, że badane piewiki były nosicielami fitoplazmy średnio w 10,6-21,0\% (M. laevis), 7,8-9,9\% (P. alienus) oraz $1,65-3,3 \%$ (H. tenuis), w testach grupowych według równania Bhattacharyya i wsp. (1979).

Celem pracy było rozpoznanie naturalnego wektora fitoplazmy 'Candidatus Phytoplasma asteris' wywołującej fyllodiozę rzepaku ozimego (B. napus) w Polsce. 


\section{Materiały i metody / Materials and methods}

\section{Założenie hodowli owadów (hodowla wyjściowa, dotyczy wariantu 1 i 2)}

W celu założenia zdrowych hodowli dwóch gatunków piewików: $M$. laevis i $P$. alienus, owady odławiano z trawiastych terenów przypolnych, w okolicy Poznania. Czerpakowania wykonano na początku czerwca. Owady hodowano w izolatorze, na zdrowym, uzyskanym z nasion, jęczmieniu (Hordeum vulgare) odmiany Nagradowicki. Hodowlę utrzymywano w warunkach zewnętrznych, pod zadaszeniem. Następnie część owadów poddano weryfikacji, by stwierdzić czy są wolne od fitoplazm. W tym celu przeprowadzono izolację DNA (deoxyribonucleic acid) owadziego z prób zbiorczych, w których na jedną próbę składało się pięć osobników danego gatunku owada. Izolacje wykonano w oparciu o kit do izolacji DNA z tkanek zwierzęcych (Qiagen). W ten sposób przygotowano dziesięć prób i poddano je testowi PCR (polymerase chain reaction) $\mathrm{w}$ dwóch rundach (Nested-PCR), $\mathrm{z}$ udziałem uniwersalnych starterów do wykrywania fitoplazm, według metodyki opisanej poniżej.

\section{Uzyskanie owadów infekcyjnych (hodowla nabywcza)}

Kolejnym etapem doświadczenia było uzyskanie kolonii owadów zakażonych fitoplazmą wywołującą fyllodiozę rzepaku (RP). Hodowlę nabywczą założono poprzez umieszczenie $\mathrm{w}$ izolatorze rzepaku $\mathrm{z}$ potwierdzoną infekcją fitoplazmą 'Candidatus Phytoplasma asteris'. Objawowe rośliny rzepaku, z wykształconymi fyllodiami w miejscu łuszczyn, pozyskano z pola uprawnego w Gorzyczkach i Winnej Górze (2011) oraz Borowie (2012). Infekcję fitoplazmatyczną potwierdzono standardowym testem do identyfikacji fitoplazm, izolując totalne DNA z fyllodiów rośliny i wykonując reakcje PCR z zastosowaniem starterów specyficznych dla genomu fitoplazmy. Następnie odczytano sekwencję uzyskanych fragmentów DNA korzystając z serwisu sekwencjonującego. Otrzymane odczyty analizowano za pomocą algorytmów dostępnych na stronie internetowej NCBI (National Center for Biotechnology Information), poprzez ich porównanie $\mathrm{z}$ sekwencjami zgromadzonymi w bazie Gen Bank. W celu zwiększenia przeżywalności owadów i zapewnienia ciągłości hodowli, $\mathrm{w}$ izolatorze wraz $\mathrm{z}$ zakażonym rzepakiem, umieszczono doniczkę $\mathrm{z}$ jęczmieniem. Owady hodowane wyłącznie na roślinach rzepaku, cechowały się wysoką śmiertelnością. Stąd konieczność zastosowania urozmaiconego pokarmu poprzez wprowadzenie, preferowanego przez piewiki, jęczmienia. Hodowlę prowadzono przez 14 dni w temperaturze pokojowej (23$25^{\circ} \mathrm{C}$ ), przy długości dnia równej 16 godzin. Po tym czasie owady wykorzystano w pierwszym wariancie doświadczenia. Pozostałe owady, głównie M. laevis, pozostawiono w izolatorze do obserwacji ich rozwoju. Hodowlę utrzymywano w warunkach zewnętrznych, pod zadaszeniem, aż do momentu zakończenia cyklu rozwojowego owadów jesienią.

\section{Przenoszenie fitoplazm na rośliny (inokulacja)}

\section{Wariant 1: przenoszenie fitoplazmy $z$ chorej rośliny rzepaku ozimego na mlode siewki rzepaku jarego oraz rośliny testowe}

W wariancie pierwszym doświadczenia, testy na przenoszenie wykonano pod szklanymi kloszami nakładanymi na pojedyncze doniczki. Potencjalnie infekcyjne owady umieszczano na młodych, dwutygodniowych siewkach rzepaku jarego odmiany Huzar wysianych wraz z kilkoma źdźbłami młodego jęczmienia (H. vulgare) odmiany Nagradowicki. Dodatkowo testowano przeniesienie fitoplazmy fyllodiozy rzepaku na rośliny testowe, tj. bób (Vicia faba) i katarantus różowy (Catharantus roseus). Katarantus, w Polsce często błędnie nazywany barwinkiem, jest rośliną popularnie wykorzystywaną w badaniach nad fitoplazmami, ze względu na podatność na zainfekowanie większością szczepów fitoplazm. Również rośliny bobu są używane $\mathrm{w}$ pracach $\mathrm{z}$ fitoplazmami, ze względu na udowodnioną podatność na zakażenie tym patogenem.

Tabela 1. Wyniki testów przenoszenia fitoplazmy 'Candidatus Phytoplasma asteris’ z udziałem Macrosteles laevis na rzepak i jęczmień. Kolonie owadów oznaczone według miejscowości pochodzenia inokulum: Gor. - Gorzyczki, W.G. - Winna Góra, Bor. Borowo, 0 - zaginiony owad, *identyfikacja metodą PCR wraz z sekwencjonowaniem produktów, M. laevis - Macrosteles laevis

Table 1. Results of transmission trials on 'Candidatus Phytoplasma asteris' with Macrosteles laevis to rapeseed and barley. Insect colonies marked according to origin of inoculum: Gor. - Gorzyczki, W.G. - Winna Góra, Bor. - Borowo, 0 - lost insect, *identification by PCR assays and sequencing of the products, M. laevis - Macrosteles laevis

\begin{tabular}{|c|c|c|c|c|c|}
\hline $\begin{array}{c}\text { Powtórzenie } \\
\text { (doniczka) } \\
\text { Replication (pod) }\end{array}$ & $\begin{array}{l}\text { Roślina testowa } \\
\text { Test plant }\end{array}$ & $\begin{array}{l}\text { Identyfikacja } \\
\text { fitoplazmy* } \\
\text { Phytoplasma } \\
\text { identification }\end{array}$ & $\begin{array}{l}\text { Gatunek owada } \\
\text { Insect species }\end{array}$ & $\begin{array}{l}\text { Kolonia owadów } \\
\text { Insect colony }\end{array}$ & $\begin{array}{c}\text { Identyfikacja } \\
\text { fitoplazmy* } \\
\text { Phytoplasma } \\
\text { identification }\end{array}$ \\
\hline 1 & 2 & 3 & 4 & 5 & 6 \\
\hline 1 & $\begin{array}{l}\text { rzepak } \\
\text { rapeseed } \\
\text { jęczmień } \\
\text { barley }\end{array}$ & - & $\begin{array}{l}\text { M. laevis } \\
\text { M. laevis } \\
\text { M. laevis } \\
\text { M. laevis } \\
\text { M. laevis }\end{array}$ & $\begin{array}{l}\text { Gor. } \\
\text { Gor. } \\
\text { Gor. } \\
\text { Gor. } \\
\text { Gor. }\end{array}$ & $\begin{array}{l}+ \\
- \\
+ \\
+ \\
0\end{array}$ \\
\hline
\end{tabular}




\begin{tabular}{|c|c|c|c|c|c|}
\hline 1 & 2 & 3 & 4 & 5 & 5 \\
\hline 2 & $\begin{array}{c}\text { rzepak } \\
\text { rapeseed } \\
\text { jęczmień } \\
\text { barley }\end{array}$ & - & $\begin{array}{l}\text { M. laevis } \\
\text { M. laevis } \\
\text { M. laevis } \\
\text { M. laevis } \\
\text { M. laevis }\end{array}$ & $\begin{array}{l}\text { Gor. } \\
\text { Gor. } \\
\text { Gor. } \\
\text { Gor. } \\
\text { Gor. }\end{array}$ & $\begin{array}{l}+ \\
0 \\
0 \\
0 \\
0\end{array}$ \\
\hline 3 & $\begin{array}{c}\text { rzepak } \\
\text { rapeseed } \\
\text { jęczmień } \\
\text { barley }\end{array}$ & $\begin{array}{l}- \\
+\end{array}$ & $\begin{array}{l}\text { M. laevis } \\
\text { M. laevis } \\
\text { M. laevis } \\
\text { M. laevis } \\
\text { M. laevis }\end{array}$ & $\begin{array}{l}\text { Gor. } \\
\text { Gor. } \\
\text { Gor. } \\
\text { Gor. } \\
\text { Gor. }\end{array}$ & $\begin{array}{l}+ \\
+ \\
+ \\
+ \\
0\end{array}$ \\
\hline 13 & $\begin{array}{c}\text { rzepak } \\
\text { rapeseed } \\
\text { jęczmień } \\
\text { barley }\end{array}$ & $\begin{array}{l}- \\
-\end{array}$ & $\begin{array}{l}\text { M. laevis } \\
\text { M. laevis } \\
\text { M. laevis } \\
\text { M. laevis } \\
\text { M. laevis }\end{array}$ & $\begin{array}{l}\text { W.G. } \\
\text { W.G. } \\
\text { W.G. } \\
\text { W.G. } \\
\text { W.G. }\end{array}$ & $\begin{array}{l}+ \\
- \\
- \\
- \\
0\end{array}$ \\
\hline 14 & $\begin{array}{c}\text { rzepak } \\
\text { rapeseed } \\
\text { jęczmień } \\
\text { barley }\end{array}$ & $\begin{array}{l}- \\
-\end{array}$ & $\begin{array}{l}\text { M. laevis } \\
\text { M. laevis } \\
\text { M. laevis } \\
\text { M. laevis } \\
\text { M. laevis }\end{array}$ & $\begin{array}{l}\text { W.G. } \\
\text { W.G. } \\
\text { W.G. } \\
\text { W.G. } \\
\text { W.G. }\end{array}$ & $\begin{array}{l}- \\
- \\
- \\
+ \\
+\end{array}$ \\
\hline 16 & $\begin{array}{l}\text { rzepak } \\
\text { rapeseed } \\
\text { jęczmień } \\
\text { barley }\end{array}$ & $\begin{array}{l}- \\
-\end{array}$ & $\begin{array}{l}\text { M. laevis } \\
\text { M. laevis } \\
\text { M. laevis } \\
\text { M. laevis } \\
\text { M. laevis }\end{array}$ & $\begin{array}{l}\text { W.G. } \\
\text { W.G. } \\
\text { W.G. } \\
\text { W.G. } \\
\text { W.G. }\end{array}$ & $\begin{array}{l}+ \\
- \\
- \\
0 \\
0\end{array}$ \\
\hline 21 & $\begin{array}{c}\text { rzepak } \\
\text { rapeseed } \\
\text { jęczmień } \\
\text { barley }\end{array}$ & + & $\begin{array}{l}\text { M. laevis } \\
\text { M. laevis }\end{array}$ & $\begin{array}{l}\text { W.G. } \\
\text { W.G. }\end{array}$ & $\begin{array}{l}- \\
0\end{array}$ \\
\hline 22 & $\begin{array}{c}\text { rzepak } \\
\text { rapeseed } \\
\text { jęczmień } \\
\text { barley }\end{array}$ & $\begin{array}{l}- \\
+\end{array}$ & $\begin{array}{l}\text { M. laevis } \\
\text { M. laevis }\end{array}$ & $\begin{array}{l}\text { Bor. } \\
\text { Bor. }\end{array}$ & $\begin{array}{l}+ \\
-\end{array}$ \\
\hline 23 & $\begin{array}{c}\text { rzepak } \\
\text { rapeseed } \\
\text { jęczmień } \\
\text { barley }\end{array}$ & - & $\begin{array}{l}\text { M. laevis } \\
\text { M. laevis }\end{array}$ & $\begin{array}{l}\text { Bor. } \\
\text { Bor. }\end{array}$ & $\begin{array}{l}- \\
+\end{array}$ \\
\hline 24 & $\begin{array}{c}\text { rzepak } \\
\text { rapeseed } \\
\text { jęczmień } \\
\text { barley }\end{array}$ & + & $\begin{array}{l}\text { M. laevis } \\
\text { M. laevis }\end{array}$ & $\begin{array}{l}\text { Bor. } \\
\text { Bor. }\end{array}$ & $\begin{array}{l}+ \\
+\end{array}$ \\
\hline 25 & $\begin{array}{c}\text { rzepak } \\
\text { rapeseed } \\
\text { jęczmień } \\
\text { barley }\end{array}$ & - & $\begin{array}{l}\text { M. laevis } \\
\text { M. laevis }\end{array}$ & $\begin{array}{l}\text { Bor. } \\
\text { Bor. }\end{array}$ & + \\
\hline
\end{tabular}

Na rośliny umieszczone pod kloszami dodawano po 5 lub 2 owady M. laevis lub P. alienus, a w przypadku testów z katarantusem, po 3 owady (tab. 1). W kontroli negatywnej do tych samych roślin dodano owady hodowane wyłącznie na jęczmieniu (hodowla wyjściowa). Do badań użyto roślin zdrowych, uzyskanych z nasion. Po zakończeniu okresu inokulacji (10 dni), owady odławiano i testowano pod kątem obecności fitoplazmy. Zakażane rośliny pozostawiono na okres sześciu tygodni do obserwacji wykształcenia objawów chorobowych. Po tym czasie rośliny analizowano w analogiczny sposób, jak owady.
Wariant 2: przenoszenie fitoplazmy $z$ chorej rośliny rzepaku ozimego na rośliny rzepaku jarego w wieku 4-9 tygodni

$\mathrm{W}$ wariancie drugim doświadczenia, owady z kolonii „Borowo", utrzymywanej przez dwa miesiące na zakażonym rzepaku (wydłużona inokulacja) nanoszono na zdrowe rośliny rzepaku jarego odmiany Huzar w wieku: 4, 7 i 9 tygodni. Doświadczenia wykonano w izolatorach, w których na okres 14 dni, umieszczano po dwie rośliny rzepaku łącznie z 25 osobnikami $M$. laevis. Rzepak pozostawiono do obserwacji przez kolejne dwa miesiące, a po 
tym czasie z wyciętych nerwów liściowych testowanych roślin, izolowano DNA i poddawano analizie na obecność fitoplazm (poniżej).

\section{Wariant 3: zakażanie roślin rzepaku ozimego owadami pozyskanymi z pola}

Dodatkowo we wrześniu 2013 roku, wykonano zmodyfikowane doświadczenie na przenoszenie, w którym owady trzech gatunków: $M$. laevis, $P$. alienus i $H$. tenuis, pochodziły bezpośrednio z terenów uprawnych w Winnej Górze, gdzie wcześniej stwierdzono wysoki poziom porażenia rzepaku fitoplazmami. Pozyskane owady w ilości 17-40 osobników hodowano na 20 siewkach rzepaku ozimego odmiany Poznaniak oraz dodatkowo na czterech roślinach bobu i czterech roślinach grochu, przez miesiąc.

Następnie, po zakończonym okresie inkubacji, analizowano fragmenty tkanki roślin bobu i grochu na obecność DNA fitoplazmatycznego, a młode rośliny rzepaku wysadzano do gruntu i obserwowano wykształcanie się objawów infekcji na wiosnę. Doświadczenie to miało za zadanie, w możliwie najwierniejszy sposób, naśladować prawdopodobny, naturalnie zachodzący proces zakażenia roślin rzepaku ozimego $\mathrm{w}$ polu.

Schemat doświadczenia - wariant 3:

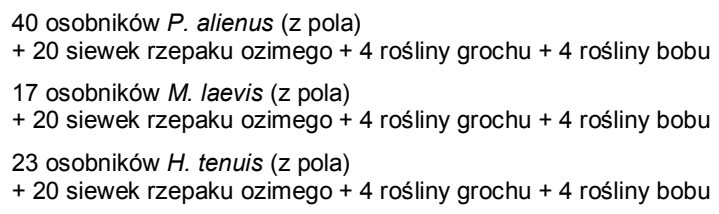

\section{Wykrywanie fitoplazm}

Fitoplazmy identyfikowano przy pomocy metod molekularnych, izolując totalne DNA $\mathrm{z}$ roślin i owadów, a następnie przeprowadzając tzw. zagnieżdżony PCR (Nested-PCR) z dwoma parami starterów. Uzyskane produkty reakcji PCR sekwencjonowano i poddawano analizie porównawczej. Na kolejne etapy identyfikacji składały się:

\section{Izolacja DNA}

Totalne DNA roślin izolowano przy pomocy buforu CTAB według metody Maixnera (Maixner i wsp. 1995). Do izolacji używano fragmentów liści i łodyg pochodzących z kilku miejsc badanej rośliny. Tkankę roślinną w ilości 1-2 gramów rozcierano w sterylnych moździerzach $\mathrm{z}$ dodatkiem $2 \mathrm{ml}$ buforu CTAB, do uzyskania jednolitej zawiesiny. Homogenat zbierano do plastikowych probówek $2 \mathrm{ml} \mathrm{i}$ inkubowano $\mathrm{w}$ temperaturze $60^{\circ} \mathrm{C}$ przez 30 min. Następnie, mieszaniny wirowano, a uzyskany supernatant poddawano ekstrakcji z mieszaniną chloroform:alkohol izoamylowy (24:1) dwukrotnie. Kwasy nukleinowe precypitowano $\mathrm{z}$ dodatkiem 0,7 objętości schłodzonego izopropanolu i inkubowano przez noc w temperaturze $-20^{\circ} \mathrm{C}$. DNA osadzono wirując przy $22000 \mathrm{~g}$ przez $5 \mathrm{~min}$. Osad przemywano $70 \%$ etanolem i zawieszano w $300 \mu$ l buforu TE (pH 8).

Owadzie DNA izolowano przy pomocy kitu Qiagen (DNeasy Blood \& Tissue Kit), rozcierając analizowane osobniki pojedynczo, przy pomocy minihomogenizatorka w probówkach typu Eppendorf. Dalsze etapy izolacji przeprowadzono zgodnie z zaleceniami producenta.

\section{Amplifikacja DNA fitoplazmatycznego}

Do wykrywania fitoplazm w preparatach DNA zastosowano reakcję Nested-PCR $\mathrm{z}$ uniwersalnymi starterami do identyfikacji fitoplazm, zaprojektowanymi do powielania genu $16 \mathrm{~S}$ rRNA oraz fragmentu genu $23 \mathrm{~S}$ rRNA. W pierwszej rundzie PCR zastosowano startery P1/P7 (Deng i Hiruki 1991; Schneider i wsp. 1995) z temperaturą przyłączania $55^{\circ} \mathrm{C}$. Produkt tej reakcji $(1,8 \mathrm{kz})$ rozcieńczano sterylną wodą destylowaną w proporcji 1:30 i tak przygotowane fragmenty DNA stanowiły matrycę w drugiej rundzie PCR ze starterami R16F2n/R16R2 (Lee i wsp. 1993), przy zastosowaniu temperatury przyłączania równiej $50^{\circ} \mathrm{C}$. Uzyskany produkt nakładano na żel agarozowy $(1,5 \%)$ w objętości $4 \mu \mathrm{l}$ i rozdzielano elektroforetycznie.

\section{Potwierdzenie obecności DNA fitoplazmatycznego}

Próby, w których w rozdziale elektroforetycznym zaobserwowano prążek o oczekiwanej długości około 1200 par zasad, sekwencjonowano. Otrzymane sekwencje porównywano z sekwencjami umieszczonymi w bazie genów Gen Bank i w ten sposób odczytywano, czy produkt PCR to rzeczywiście produkt amplifikacji genów fitoplazmatycznych.

\section{Wyniki i dyskusja / Results and discussion}

\section{Hodowla wyjściowa}

Wstępne próby utworzenia hodowli wyjściowej skoczków M. laevis i $P$. alienus, na dwutygodniowych siewkach rzepaku jarego odmiany Huzar skutkowały 100\% śmiertelnością piewików, w ciągu 48 godzin od momentu rozpoczęcia hodowli. Na każdym etapie doświadczenia, w wariancie 1., obok roślin rzepaku zapewniano owadom dodatkowy pokarm w postaci jęczmienia. Podobne działania w doświadczeniach nad skoczkiem sześciorkiem wykorzystali Kochman i Książek (1964), którzy również napotkali trudności w prowadzeniu hodowli owadów wyłącznie na roślinach przez nich testowanych, tj. cebuli $\mathrm{i}$ astrze.

Stosując testy PCR wykrywające DNA fitoplazmatyczne zbadano zdrowotność kolonii wyjściowej. W żadnej z badanych dziesięciu prób zbiorczych, nie wykryto obecności komórek fitoplazmatycznych. Tym samym uznano kolonię owadów za zdrową.

\section{Hodowla nabyweza}

We wszystkich trzech objawowych roślinach rzepaku, użytych w doświadczeniach jako inokulum potwierdzono infekcję fitoplazmatyczną. Sekwencje uzyskane z zainfekowanych roślin rzepaku były identyczne $\mathrm{z}$ opisanym wcześniej izolatem fitoplazmy fyllodiozy 'RzW14', pochodzącym z Winnej Góry (nr akcesyjny HM561990). Kolonie owadów hodowanych na tych roślinach nazwano odpowiednio „Gorzyczki”, „Winna Góra” i „Borowo” (oznaczenia: Gor., W.G. i Bor.). W miarę prowadzenia 
hodowli nabywczej, którą utrzymywano jako hodowlę ciągłą zaobserwowano postępującą adaptację skoczków M. laevis do żerowania na porażonej fitoplazmą roślinie rzepaku. Owady chętnie wkłuwały się w młode, zielone tkanki drugorzędowych pędów wyrastających z przekształconych kwiatostanów chorej rośliny. Dzięki temu zjawisku, w drugim wariancie doświadczenia, skoczkami M. laevis inokulowano rzepak bez udziału jęczmienia jako rośliny towarzyszącej. Podobną adaptację do alternatywnych źródeł pokarmu zaobserwował Alma i wsp. (2001) hodując cztery gatunki piewików na złocieniach (Chrysanthemum carinatum), które nie były naturalnym źródłem pokarmu dla tych owadów. Mniej liczne osobniki $P$. alienus zostały w całości wykorzystane do doświadczeń i nie utrzymywano ich w hodowli ciągłej.

Utrzymując hodowlę w warunkach zbliżonych do naturalnych, na jęczmieniu i chorym rzepaku, możliwe było zaobserwowanie stadiów rozwoju kolonii skoczka sześciorka $M$. laevis. Udowodniono tym samym, że gatunek ten, w obecnym klimacie Wielkopolski, przechodzi trzy pokolenia, a nie, jak sugerowano dawniej, dwa pokolenia (Nowacka 1982). Tę obserwację udało się potwierdzić w kolejnych, niezależnych hodowlach założonych w latach 2013 i 2014.

Jednocześnie prowadzono obserwację zmian w wyglądzie porażonej rośliny rzepaku. Z początkowo zwartych, zielonych struktur kwiatostanowych, gdzie w miejscu łuszczyn wyrastały rozdęte, podłużne, pęcherzykowate twory, a działki kielicha były trzykrotnie powiększone w stosunku do zdrowych kwiatów (rys. 1, fot. 1), z upływem czasu, wyrastały wydłużone pędy zakończone drobnymi listkami lub drobnymi strukturami przypominającymi kwiat kalafiora (rys. 1, fot. 3). Te nowe pędy, początkowo rozwijały się wewnątrz pęcherzykowatych tworów, by później doprowadzić do ich pęknięcia i zaschnięcia. Czasem w miejscu zakończenia drugorzędowych pędów rozwijały się struktury $\mathrm{z}$ powiększonym słupkiem zaopatrzone w żółte płatki korony, przypominające kwiaty (rys. 1, fot. 2). Inne pędy porażonego

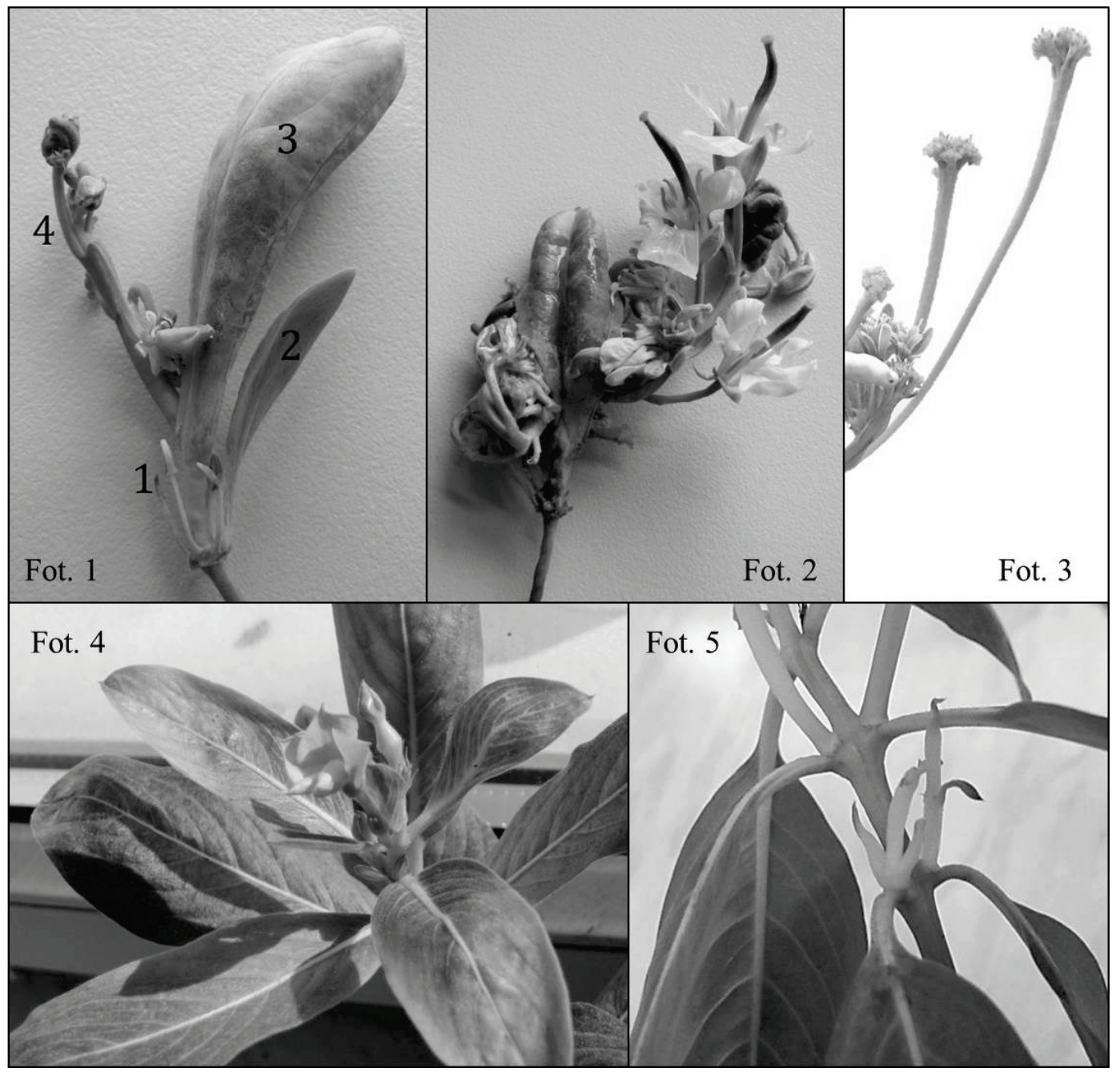

Fot. 1. Zmodyfikowany kwiat rzepaku tzw. fyllodium: 1 - pręciki, 2 - powiększona działka kielicha, 3 - „rozdęty”, workowaty słupek, 4 - pędy drugorzędowe wyrastające z wnętrza słupka, Fot. 2. Fyllodium. Wyrastające $z$ wnętrza workowatego słupka drugorzędowe pędy wraz z kwiatami, Fot. 3. Fyllodium. Drugorzędowe pędy zakończone tworami przypominającymi kwiat kalafiora, Fot. 4. Przekształcone, zielone kwiaty katarantusa, Fot. 5. Zdeformowane pędy boczne wyrastające z merystemów bocznych katarantusa

Pic. 1. Modified flower of oilseed rape - phyllody: 1 - stamen, 2 - enlarged sepals, 3 - swollen, bladder-like, pistil, 4 - secondary shoots growing out of pistil, Pic. 2 . Phyllody. Secondary shoots containing flowers growing out from bladder-like pistil, Pic. 3. Phyllody. Secondary shoots ended with cauliflower resembling structures, Pic. 4. Modified, green flowers of Madagascar periwinkle, Pic. 5. Deformed auxiliary shoots growing out of auxiliary buds of Madagascar periwinkle

Rys. 1. Objawy porażenia fitoplazmą fyllodiozy rzepaku roślin rzepaku i katarantusa

Fig. 1. Symptoms of rapeseed phyllody phytoplasma infection of oilseed rape and Madagascar periwinkle 
Tabela 2. Wyniki testów przenoszenia fitoplazmy 'Candidatus Phytoplasma asteris' z udziałem Macrosteles laevis na katarantusa, bób i jęczmień. Kolonie owadów oznaczone według miejscowości pochodzenia inokulum: Gor. - Gorzyczki, W.G. - Winna Góra, Bor. - Borowo, 0 - zaginiony owad, *identyfikacja metodą PCR wraz z sekwencjonowaniem produktów, M. laevis - Macrosteles laevis

Table 2. Results of transmission trials on 'Candidatus Phytoplasma asteris' with Macrosteles laevis to Madagascar periwinkle, broad bean and barley. Insect colonies marked according to origin of inoculum: Gor. - Gorzyczki, W.G. - Winna Góra, Bor. - Borowo, 0 - lost insect, *identification by PCR assays and sequencing of the products, M. laevis - Macrosteles laevis

\begin{tabular}{|c|c|c|c|c|c|}
\hline $\begin{array}{c}\text { Powtórzenie } \\
\text { (doniczka) } \\
\text { Replication (pod) }\end{array}$ & $\begin{array}{l}\text { Roślina testowa } \\
\text { Test plant }\end{array}$ & $\begin{array}{c}\text { Identyfikacja } \\
\text { fitoplazmy* } \\
\text { Phytoplasma } \\
\text { identification }\end{array}$ & $\begin{array}{l}\text { Gatunek owada } \\
\text { Insect species }\end{array}$ & $\begin{array}{l}\text { Kolonia owadów } \\
\text { Insect colony }\end{array}$ & $\begin{array}{c}\text { Identyfikacja } \\
\text { fitoplazmy* } \\
\text { Phytoplasma } \\
\text { identification }\end{array}$ \\
\hline 7 & $\begin{array}{l}\text { katarantus } \\
\text { periwinkle } \\
\text { jęczmień } \\
\text { barley }\end{array}$ & $\begin{array}{l}+ \\
-\end{array}$ & $\begin{array}{l}\text { M. laevis } \\
\text { M. laevis } \\
\text { M. laevis }\end{array}$ & $\begin{array}{l}\text { Gor. } \\
\text { Gor. } \\
\text { Gor. }\end{array}$ & $\begin{array}{l}+ \\
- \\
+\end{array}$ \\
\hline 11 & $\begin{array}{l}\text { katarantus } \\
\text { periwinkle } \\
\text { jęczmien } \\
\text { barley }\end{array}$ & $\begin{array}{l}- \\
-\end{array}$ & $\begin{array}{l}\text { M. laevis } \\
\text { M. laevis } \\
\text { M. laevis }\end{array}$ & $\begin{array}{l}\text { W.G. } \\
\text { W.G. } \\
\text { W.G. }\end{array}$ & $\begin{array}{l}- \\
- \\
+\end{array}$ \\
\hline 12 & $\begin{array}{l}\text { katarantus } \\
\text { periwinkle } \\
\text { jęczmień } \\
\text { barley }\end{array}$ & $\begin{array}{l}+ \\
+\end{array}$ & $\begin{array}{l}\text { M. laevis } \\
\text { M. laevis } \\
\text { M. laevis }\end{array}$ & $\begin{array}{l}\text { W.G. } \\
\text { W.G. } \\
\text { W.G. }\end{array}$ & $\begin{array}{l}+ \\
- \\
0\end{array}$ \\
\hline 17 & $\begin{array}{l}\text { katarantus } \\
\text { periwinkle }\end{array}$ & - & $\begin{array}{l}\text { M. laevis } \\
\text { M. laevis } \\
\text { M. laevis }\end{array}$ & $\begin{array}{l}\text { W.G. } \\
\text { W.G. } \\
\text { W.G. }\end{array}$ & $\begin{array}{l}- \\
+ \\
-\end{array}$ \\
\hline 18 & $\begin{array}{l}\text { katarantus } \\
\text { periwinkle }\end{array}$ & + & $\begin{array}{l}\text { M. laevis } \\
\text { M. laevis } \\
\text { M. laevis }\end{array}$ & $\begin{array}{l}\text { W.G. } \\
\text { W.G. } \\
\text { W.G. }\end{array}$ & $\begin{array}{l}+ \\
- \\
+\end{array}$ \\
\hline 27 & $\begin{array}{l}\text { katarantus } \\
\text { periwinkle }\end{array}$ & + & $\begin{array}{l}\text { M. laevis } \\
\text { M. laevis }\end{array}$ & $\begin{array}{l}\text { Bor. } \\
\text { Bor. }\end{array}$ & $\begin{array}{l}+ \\
0\end{array}$ \\
\hline 19 & $\begin{array}{c}\text { bób } \\
\text { broad bean }\end{array}$ & + & $\begin{array}{l}\text { M. laevis } \\
\text { M. laevis }\end{array}$ & $\begin{array}{l}\text { W.G. } \\
\text { W.G. }\end{array}$ & $\begin{array}{l}- \\
+ \\
+\end{array}$ \\
\hline 26 & $\begin{array}{c}\text { bób } \\
\text { broad bean }\end{array}$ & - & $\begin{array}{l}\text { M. laevis } \\
\text { M. laevis }\end{array}$ & $\begin{array}{l}\text { Bor. } \\
\text { Bor. }\end{array}$ & $\begin{array}{l}- \\
+ \\
\end{array}$ \\
\hline
\end{tabular}

Tabela 3. Wyniki testów przenoszenia fitoplazmy 'Candidatus Phytoplasma asteris' z udziałem Psammotettix alienus na rzepak, katarantusa, bób i jęczmień. Kolonie owadów oznaczone według miejscowości pochodzenia inokulum: Gor. - Gorzyczki, W.G. - Winna Góra, Bor. - Borowo, 0 - zaginiony owad, *identyfikacja metodą PCR wraz z sekwencjonowaniem produktów, P. alienus - Psammotettix alienus

Table 3. Results of transmission trials on 'Candidatus Phytoplasma asteris' with Psammotettix alienus to rapeseed, Madagascar periwinkle, broad bean and barley. Insect colonies marked according to origin of inoculum: Gor. - Gorzyczki, W.G. - Winna Góra, Bor. - Borowo, 0 - lost insect, *identification by PCR assays and sequencing of the products, P. alienus - Psammotettix alienus

\begin{tabular}{|c|c|c|c|c|c|}
\hline $\begin{array}{c}\text { Powtórzenie } \\
\text { (doniczka) } \\
\text { Replication (pod) }\end{array}$ & $\begin{array}{c}\text { Roślina testowa } \\
\text { Test plant }\end{array}$ & $\begin{array}{l}\text { Identyfikacja } \\
\text { fitoplazmy* } \\
\text { Phytoplasma } \\
\text { identification }\end{array}$ & $\begin{array}{l}\text { Gatunek owada } \\
\text { Insect species }\end{array}$ & $\begin{array}{l}\text { Kolonia owadów } \\
\text { Insect colony }\end{array}$ & $\begin{array}{c}\text { Identyfikacja } \\
\text { fitoplazmy* } \\
\text { Phytoplasma } \\
\text { identification }\end{array}$ \\
\hline 1 & 2 & 3 & 4 & 5 & 6 \\
\hline 4 & $\begin{array}{c}\text { rzepak } \\
\text { rapeseed } \\
\text { jęczmień } \\
\text { barley }\end{array}$ & - & $\begin{array}{l}\text { P. alienus } \\
P . \text { alienus } \\
P . \text { alienus } \\
P . \text { alienus } \\
P . \text { alienus }\end{array}$ & $\begin{array}{l}\text { Gor. } \\
\text { Gor. } \\
\text { Gor. } \\
\text { Gor. } \\
\text { Gor. }\end{array}$ & $\begin{array}{l}- \\
- \\
- \\
- \\
0\end{array}$ \\
\hline 5 & $\begin{array}{l}\text { rzepak } \\
\text { rapeseed } \\
\text { jęczmień } \\
\text { barley }\end{array}$ & $\begin{array}{l}- \\
-\end{array}$ & $\begin{array}{l}\text { P. alienus } \\
\text { P. alienus } \\
\text { P. alienus } \\
\text { P. alienus } \\
\text { P. alienus }\end{array}$ & $\begin{array}{l}\text { Gor. } \\
\text { Gor. } \\
\text { Gor. } \\
\text { Gor. } \\
\text { Gor. }\end{array}$ & $\begin{array}{l}- \\
- \\
- \\
- \\
-\end{array}$ \\
\hline
\end{tabular}




\begin{tabular}{|c|c|c|c|c|c|}
\hline 1 & 2 & 3 & 4 & 5 & 6 \\
\hline 6 & $\begin{array}{l}\text { rzepak } \\
\text { rapeseed } \\
\text { jęczmień } \\
\text { barley }\end{array}$ & - & $\begin{array}{l}\text { P. alienus } \\
\text { P. alienus } \\
\text { P. alienus } \\
\text { P. alienus } \\
\text { P. alienus }\end{array}$ & $\begin{array}{l}\text { Gor. } \\
\text { Gor. } \\
\text { Gor. } \\
\text { Gor. } \\
\text { Gor. }\end{array}$ & $\begin{array}{l}- \\
- \\
- \\
- \\
0\end{array}$ \\
\hline 9 & $\begin{array}{l}\text { rzepak } \\
\text { rapeseed } \\
\text { jęczmień } \\
\text { barley }\end{array}$ & $\begin{array}{l}- \\
-\end{array}$ & $\begin{array}{l}\text { P. alienus } \\
P . \text { alienus } \\
P . \text { alienus } \\
P . \text { alienus } \\
P \text {. alienus }\end{array}$ & $\begin{array}{l}\text { Gor. } \\
\text { Gor. } \\
\text { Gor. } \\
\text { Gor. } \\
\text { Gor. }\end{array}$ & $\begin{array}{l}- \\
- \\
- \\
- \\
-\end{array}$ \\
\hline 10 & $\begin{array}{c}\text { rzepak } \\
\text { rapeseed } \\
\text { jęczmień } \\
\text { barley }\end{array}$ & $\begin{array}{l}- \\
-\end{array}$ & $\begin{array}{l}\text { P. alienus } \\
\text { P. alienus }\end{array}$ & $\begin{array}{l}\text { Gor. } \\
\text { Gor. }\end{array}$ & $\begin{array}{l}- \\
-\end{array}$ \\
\hline 15 & $\begin{array}{l}\text { rzepak } \\
\text { rapeseed } \\
\text { jęczmień } \\
\text { barley }\end{array}$ & - & $\begin{array}{l}\text { P. alienus } \\
\text { P. alienus } \\
\text { P. alienus } \\
\text { P. alienus } \\
\text { P. alienus }\end{array}$ & $\begin{array}{l}\text { W.G. } \\
\text { W.G. } \\
\text { W.G. } \\
\text { W.G. } \\
\text { W.G. }\end{array}$ & $\begin{array}{l}- \\
- \\
- \\
0 \\
0\end{array}$ \\
\hline 8 & $\begin{array}{c}\text { katarantus } \\
\text { periwinkle } \\
\text { jęczmień } \\
\text { barley }\end{array}$ & - & $\begin{array}{l}\text { P. alienus } \\
\text { P. alienus } \\
\text { P. alienus }\end{array}$ & $\begin{array}{l}\text { Gor. } \\
\text { Gor. } \\
\text { Gor. }\end{array}$ & $\begin{array}{l}- \\
- \\
-\end{array}$ \\
\hline 20 & $\begin{array}{c}\text { bób } \\
\text { broad bean }\end{array}$ & - & $\begin{array}{l}\text { P. alienus } \\
\text { P. alienus }\end{array}$ & $\begin{array}{l}\text { W.G. } \\
\text { W.G. }\end{array}$ & $\begin{array}{l}- \\
0\end{array}$ \\
\hline
\end{tabular}

Tabela 4. Sumaryczne wyniki testów przenoszenia fitoplazmy 'Candidatus Phytoplasma asteris' z udziałem Macrosteles laevis $\mathrm{W}$ wariancie 1. doświadczenia

Table 4. Summary of results of transmission trials on 'Candidatus Phytoplasma asteris' with Macrosteles laevis in the experiment variant 1

\begin{tabular}{l|c|c|c}
\hline \multicolumn{1}{c|}{$\begin{array}{c}\text { Roślina testowa } \\
\text { Test plant }\end{array}$} & $\begin{array}{c}\text { Liczba powtórzeń } \\
\text { przenoszenia } \\
\text { Number of replications } \\
\text { of transmission }\end{array}$ & $\begin{array}{c}\text { Liczba zainfekowanych roślin } \\
\text { (wynik pozytywn) } \\
\text { Number of infected plants } \\
\text { (positive result) }\end{array}$ & $\begin{array}{c}\text { Liczba negatywnych } \\
\text { Number of negatives }\end{array}$ \\
\hline $\begin{array}{l}\text { Rzepak - Rapeseed } \\
\text { (Brassica napus) }\end{array}$ & 11 & 0 & 11 \\
\hline $\begin{array}{l}\text { Jęczmień - Barley } \\
(\text { Hordeum vulgare })\end{array}$ & 14 & 5 & 9 \\
\hline $\begin{array}{l}\text { Katarantus różowy - Madagascar periwinkle } \\
\text { (Catharantus roseus) }\end{array}$ & 9 & 4 & 5 \\
\hline $\begin{array}{l}\text { Bób - Broad bean } \\
(\text { Vicia faba) }\end{array}$ & 2 & 1 & 1 \\
\hline
\end{tabular}

rzepaku, choć nie wykształcały fyllodiów, to również nie zawiązywały nasion, a ich łuszczyny były puste. Choć większość pędów rośliny rzepaku wraz z dojrzewaniem, stopniowo zasychała, to jednak pędy drugorzędowe pozostawały zielone do końca sierpnia. We wrześniu rośliny zamierały.

\section{Inokulacja fitoplazmą roślin testowych}

W wariancie pierwszym doświadczenia, z dwóch badanych gatunków skoczków, tylko $M$. laevis nabywał fitoplazmę. Około 55\% żywych i martwych owadów, zebranych po zakończonym doświadczeniu, było nosi- cielem fitoplazmy $\mathrm{w}$ teście PCR (tab. 1, 2). W testach z tym skoczkiem uzyskano przeniesienie fitoplazmy wywołującej fyllodiozę rzepaku na rośliny testowe: jęczmień $(5 \times)$, bób $(1 \times)$ i katarantus $(4 \times)$, ale nie potwierdzono przenoszenia fitoplazmy na rzepak jary. Owad $P$. alienus nie nabywał fitoplazmy $\mathrm{z}$ zainfekowanego rzepaku ozimego, stąd wszystkie doświadczenia na przenoszenie, przeprowadzone $\mathrm{z}$ tym owadem, dały wynik negatywny (tab. 3). Tabela 4. podsumowuje wyniki uzyskane $\mathrm{z}$ testów przenoszenia fitoplazmy fyllodiozy rzepaku w wariancie 1. doświadczenia. Najskuteczniejsze przenoszenie fitoplazmy wywołującej fyllodiozę uzyskano w przypadku katarantusa różowego (4 rośliny na 6 tes- 
towanych). Porażony katarantus, w jednym przypadku, wykształcił w miejscu różowych, kwiaty zielone (rys. 1, fot. 4). Inna roślina $C$. roseus miała silnie zdeformowane pędy $\mathrm{z}$ dodatkowo rozwijającymi się pędami $\mathrm{z}$ merystemów bocznych (rys. 1, fot. 5). Infekcja kolejnej rośliny katarantusa objawiała się jasnozielonymi, połyskliwymi liśćmi. Natomiast jedna z roślin nie wykazywała żadnych symptomów infekcji pomimo pozytywnego rezultatu testu na obecność fitoplazmy. Nie zaobserwowano żadnych widocznych objawów porażenia jęczmienia i rzepaku w ciągu półtoramiesięcznej inkubacji tych roślin. U zainfekowanych roślin bobu również nie zaobserwowano żadnych specyficznych objawów porażenia. W testach PCR roślin użytych w kontroli ujemnej nie wykryto DNA fitoplazmatycznego. Uzyskano 35\% skuteczność przenoszenia fitoplazmy 'Candidatus Phytoplasma asteris' na jęczmień, 44\% na katarantusa i 50\% na rośliny bobu. Skuteczność przenoszenia fitoplazmy RP na rzepak wyniosła $0 \%$. Wyniki pozytywne przeniesienia fitoplazmy RP na rośliny katarantusa, bobu i jęczmienia potwierdzają, że M. laevis jest wektorem fitoplazmy żółtaczki astra typu I-B. Jęczmień jest chętnie wybieranym źródłem pokarmu przez polifagiczne piewiki, stąd może stanowić inokulum tego patogenu. Rzepak, który w warunkach naturalnych wykazuje podatność na zakażenie fitoplazmami, nie jest zasiedlany przez skoczki (Klejdysz 2013). Silne preferencje pokarmowe owadów, mogą thumaczyć niską skalę porażania upraw rzepaku $\mathrm{w}$ warunkach naturalnych oraz wynik negatywny przenoszenia fitoplazm na rzepak w wariantach 1 i 3 doświadczenia, w których owady miały wybór pokarmu. W wariancie drugim przeprowadzonego doświadczenia, gdzie owady hodowano wyłącznie na rzepaku, przebadano łącznie dziesięć roślin, co może nie reprezentować wystarczająco zjawiska przenoszenia. Niską skalę porażenia fitoplazmami roślin w warunkach laboratoryjnych, odnotowali Kochman i Książek (1964), którzy pracując ze skoczkiem sześciorkiem, uzyskali przeniesienie żółtaczki astra $\mathrm{z}$ porażonych baldachów cebuli jedynie na dwie cebule spośród 84 testowanych. Autorzy tłumaczą to zjawisko zbyt krótkim okresem żeru nabywczego (10 dni), a tym samym niedostateczną długością okresu latencji fitoplazm w ciele owadów. $\mathrm{W}$ przeprowadzonych badaniach, w celu zwiększenia szans na przeniesienie czynnika chorobowego, w wariancie drugim doświadczenia na przenoszenie, okres nabywania fitoplazmy został wydłużony. W tym wariancie, owady M. laevis $\mathrm{z}$ hodowli nabywczej prowadzonej aż $60 \mathrm{dni}$, utrzymywano następnie na roślinach rzepaku jarego, w różnym wieku (4, 7 i 9 tygodni) przez dwa tygodnie. Również w tym doświadczeniu, nie udało się potwierdzić, że owad ten jest wektorem fitoplazmy AY 16SrI-B na rzepaku, a tym samym że odpowiada za rozprzestrzenianie fyllodiozy rzepaku. W wariancie trzecim doświadczenia na przenoszenie fitoplazmy RP, pomimo zaaranżowania naturalnego procesu zakażenia fyllodiozą, nie zaobserwowano wykształcenia się objawów fyllodiów u testowanej grupy roślin rzepaku ozimego na wiosnę, w żadnej z prób spośród trzech badanych gatunków piewików. Również testy molekularne nie potwierdziły przeniesienia fitoplazmy na rzepak oraz rośliny grochu i bobu. W osobnych testach przesiewowych wykazano, że stopień pora- żenia fitoplazmą piewików $M$. laevis, $P$. alienus i $H$. tenuis w polu, we wrześniu, jest znacznie niższy niż w miesiącach czerwiec-sierpień, stąd prawdopodobnie trudność W zainfekowaniu roślin w testach wariantu trzeciego. Niska infekcyjność piewików jesienią mogłaby również tłumaczyć, ograniczoną skalę porażeń fitoplazmami upraw rzepaku.

Uzyskane wyniki, nie wykluczają skoczka $P$. alienus jako wektora fitoplazmy RP, pokazują natomiast, że rzepak może być żywicielem ostatecznym w cyklu przenoszenia fitoplazmy przez tego owada. Dla przykładu, podgrupy żółtaczki astra I-B i I-C są przenoszone przez piewiki Euscelis incisus, E. variegatus i M. quadripunctulatus, gdy są pobierane $\mathrm{z}$ porażonych roślin zielnych, nie zaś z cyklamena, który jednak może być skutecznie zakażany przez te owady (Alma i wsp. 2000). Sugeruje to, że etap nabywania fitoplazmy, a nie inokulacji, może odgrywać kluczową rolę w efektywnym przenoszeniu patogenu.

Podsumowując, do badań nad wektorem fyllodiozy rzepaku powodowanej przez szczep AY 16SrI-B, wybrano dwa najpopularniejsze gatunki piewików występujące w polskiej entomofaunie terenów uprawnych: skoczka sześciorka $M$. laevis i zgłobika smużkowanego $P$. alienus (Klejdysz i Wałkowski 2008). W niniejszej pracy potwierdzono zdolność przenoszenia fitoplazmy fyllodiozy rzepaku na trzy gatunki roślin: jęczmień, katarantus i bób, przy pomocy $M$. laevis. Skoczek ten był już opisywany jako wektor fitoplazm w latach 60. XX wieku (Brčák 1979). Trudno jest odnieść ówczesną klasyfikację fitoplazm opartą o objawy wywoływane na wybranych gatunkach roślin i obserwacje mikroskopowe do tej współczesnej opartej na podobieństwie sekwencji zakonserwowanego genu $16 \mathrm{~S}$ rRNA. Jednak wiele wskazuje na to, że opisywana w tamtych czasach Europejska żółtaczka astra (EAY) oraz niektóre przypadki karłowacenia koniczyny (clover dwarf) powodowane były przez fitoplazmę należącą do tej samej grupy rybosomalnej, co fitoplazma fyllodiozy rzepaku, czyli 16SrI-B (Zwolińska 2011a, b). Pod koniec lat 60. na terenach współczesnej Słowacji rejestrowano przypadki żółtaczek na owsie (Vacke 1966). Skoczek sześciorek przenosił czynnik sprawczy choroby na rośliny owsa, jęczmienia, żyta, pszenicy, wiechliny rocznej (Poa annua), stokłosy polnej (Bromus arvensis), astra, szpinaku, marchwi oraz chwastów: rumianku (Matricaria chamomilla) i babki (Plantago major). W 1975 roku Musil zarejestrował przeniesienie fitoplazmy wywołującej karłowacenie koniczyny przez $M$. laevis na rośliny $\mathrm{z}$ rodziny wiechlinowatych: jęczmień dwurzędowy (Hordeum distichum), owies zwyczajny (Avena sativa) i wiechlinę roczną ( $P$. annua) (Brčák 1979). W Polsce, żółtaczkę astra udało się również przenieść doświadczalnie $\mathrm{z}$ udziałem $M$. laevis z porażonej cebuli i astra na zdrową cebulę, a także $\mathrm{z}$ przymiotna kanadyjskiego (Conyza canadiensis) z objawami infekcji na katarantusa (Kochman i Książek 1964). W 2005 roku Kamińska i Śliwa zaobserwowały przeniesienie żółtaczki astra przez $M$. laevis $\mathrm{z}$ aksamitki rozpierzchłej (Tagetes patula) na młode siewki lilii (Lilium longiflorum) oraz na katarantusa (C. roseus).

W przeprowadzonych doświadczeniach, drugi testowany gatunek piewika - zgłobik smużkowy $(P$. alienus $)$ nie 
nabywał fitoplazmy $\mathrm{z}$ porażonego fyllodiozą rzepaku. $P$. alienus był opisywany jako wektor fitoplazm. Przenosił fitoplazmę chlorozy pszenicy (zwaną dawniej mykoplazmą), która prawdopodobnie odpowiada współczesnym żółtaczkom astra, na pszenicę, jęczmień, owies, chryzantemę oraz katarantusa (Ploaie 1981). Potwierdzono także możliwość wprowadzenia do sztucznej pożywki komórek żółtaczki astra podgrupy 16SrI-B przez tego owada (Landi i wsp. 2013).

Inny polifagiczny gatunek Hardia tenuis, który występuje w całej Europie i północnej Ameryce, i jest coraz liczniej spotykany w Polsce, nie był dotąd notowany jako wektor fitoplazm, jednak wykryto, że może być nosicielem żółtaczek astra podgrup 16SrI-B i $16 \mathrm{SrI}-\mathrm{F}$ (Orsagova i wsp. 2011).

Większość poznanych wektorów owadzich fitoplazm jest polifagiczna, co oznacza, że mogą się odżywiać wieloma gatunkami roślin, w tym powszechnych chwastów i roślin wieloletnich, np. drzew i krzewów. Stwarza to duży potencjał do rozprzestrzeniania się choroby fitoplazmatycznej, gdyż alternatywne rośliny żywicielskie stanowią naturalny rezerwuar patogenu. Piewik będący wektorem pozyskuje fitoplazmę wysysając sok zainfekowanej rośliny i roznosi fitoplazmę, w ciągu całego swojego życia, na zdrowe rośliny wywołując u nich chorobę. Identyfikacja wektora odpowiedzialnego za rozprzestrzenianie się danej choroby, jest podstawowym krokiem w epidemiologii chorób roślin. Przeprowadzenie doświadczenia przenoszenia $\mathrm{z}$ kolonią owadów i testowanymi roślinnymi gospodarzami jest niezbędne w procesie identyfikacji wektora. Należy podkreślić, że wykazanie obecności komórek fitoplazmy w ciele owada metodą $\mathrm{PCR}$, nie jest równoznaczne $\mathrm{z}$ potwierdzeniem, że owad ten jest wektorem. Każdy owad żywiący się sokiem roślin może nabyć do swojego układu pokarmowego komórki fitoplazmy i być przez nie skontaminowanym. Tylko żywe fitoplazmy, które na drodze endocytozy dostaną się do ślinianek owada, będą miały szansę być przekazane na kolejne rośliny.
Ciekawym aspektem w epidemiologii fyllodiozy rzepaku jest fakt, że choć patogen przenoszony jest przez owady, co zazwyczaj wiąże się z dużą skalą zjawiska, to jednak charakterystyczne objawy fyllodiów wykształcają pojedyncze rośliny rzepaku na polu. Warto podkreślić, że przy sprzyjających warunkach biotyczno-klimatycznych, sytuacja ta może raptownie ulec zmianie, a fyllodioza rzepaku może stać się realnym zagrożeniem dla upraw.

\section{Wnioski / Conclusions}

1. Hodowane na rzepaku skoczki M. laevis były zdolne do nabycia fitoplazmy 'Candidatus Phytoplasma asteris' grupy rybosomalnej $16 \mathrm{SrI}-\mathrm{B}$ (infekcyjne), natomiast skoczki $P$. alienus, odławiane na polu, wielokrotnie zawierały komórki fitoplazm w swoim organizmie, to jednak hodowane na rzepaku, nie nabywały fitoplazmy (owady nieinfekcyjne).

2. W wielokrotnych powtórzeniach doświadczeń na przenoszenie wykazano, że $M$. laevis skutecznie przenosi fitoplazmę wywołującą fyllodiozę rzepaku na takie rośliny, jak jęczmień, bób czy katarantus różowy, jednak niezdolny jest do zakażenia młodych roślin rzepaku jarego i ozimego. Tym samym, nie uzyskano potwierdzenia, że gatunek ten jest wektorem badanej choroby.

3. M. laevis jest wektorem fitoplazm z grupy żółtaczki astra 16SrI-B, a skuteczność przenoszenia zależna jest od gatunku roślin poddanych zakażeniu.

\section{Podziękowanie / Acknowledgements}

Badania zostały sfinansowane ze środków Narodowego Centrum Nauki przyznanych na podstawie decyzji numer DEC-2011/01/N/NZ9/06512.

\section{Literatura / References}

Alma A., Marzachi C., d'Aquilio M., Bosco D. 2000. Cyclamen (Cyclamen persicum L.): a dead-end host species for 16Sr-IB and -IC subgroup phytoplasmas. Annals of Applied Biology 136 (2): 173-178.

Alma A., Palermo S., Boccardo G., Conti M. 2001. Transmission of chrysanthemum yellows, a subgroup 16SrI-B phytoplasma, to grapevine by four leafhopper species. Journal of Plant Pathology 83 (3): 181-187.

Bertaccini A., Duduk B., Paltrinieri S., Contaldo N. 2014. Phytoplasmas and phytoplasma diseases: a severe threat to agriculture. American Journal of Plant Sciences 5: 1763-1788.

Bhattacharyya G.K., Karandinos M.G., Defoliart G.R. 1979. Point estimates and confidence intervals for infection rates using pooled organisms in epidemiologic studies. American Journal of Epidemiology 109 (2): 124-131.

Bosco D., Minucci C., Boccardo G., Conti M. 1997. Differential acquisition of chrysanthemum yellows phytoplasma by three leafhopper species. Entomologia Experimentalis et Applicata 83 (2): 219-224.

Brčák J. 1979. Leafhopper and planthopper vectors of plant disease agents in central and southern Europe. p. 97-146. In: "Leafhopper Vectors and Plant Disease Agents" (K. Maramorosch, K.F. Harris, eds.). Academic Press, London, UK, 654 pp.

Deng S., Hiruki C. 1991. Amplification of 16S rRNA genes from culturable and nonculturable mollicutes. Journal of Microbiological Methods 14 (1): 53-61.

Ebbert M.A., Jeffers D.P., Harrison N.A., Nault L.R. 2001. Lack of specificity in the interaction between two maize stunting pathogens and field collected Dalbulus leafhoppers. Entomologia Experimentalis et Applicata 101 (1): 49-57.

Fránová J., Špak J. 2013. First report of a 16SrI-C phytoplasma infecting celery (Apium graveolens) with stunting, bushy top and phyllody in the Czech Republic. Journal of Phytopathology 161 (9): 666-670.

Gatineau F., Larrue J., Clair D., Lorton F., Richard-Molard M., Boudon-Padieu E. 2001. A new natural planthopper vector of stolbur phytoplasma in the genus Pentastiridius (Hemiptera: Cixiidae). European Journal of Plant Pathology 107 (3): $263-271$. 
Kamińska M., Śliwa H. 2005. The reaction of Catharanthus roseus test plant to infection with two polish strains of Aster yellows phytoplasma. Phytopathologia Polonica 37: 23-32.

Klejdysz T. 2013. Piewiki (Hemiptera: Cicadomorpha \& Fulgoromorpha) jako składnik szkodliwej entomofauny ważniejszych upraw w Polsce. Rozprawa doktorska. Instytut Ochrony Roślin - Państwowy Instytut Badawczy, Poznań, 250 ss.

Klejdysz T., Wałkowski W. 2008. Dynamika liczebności wybranych populacji piewików (Hemiptera: Auchenorrhyncha) występujących na jęczmieniu jarym w Winne Górze na tle zmian klimatycznych. [Frequency dynamics of the selected populations of Auchenorrhyncha (Hemiptera) occurring on spring barley at Winna Góra on background of climatic change]. Progress in Plant Protection/Postępy w Ochronie Roślin 48 (3): 864-872.

Kochman J., Książek D. 1964. Badania nad przenoszeniem wirusów żółtaczki astra i żółtej karłowatości cebuli przy udziale skoczków Macrosteles laevis Rib. Acta Agrobotanica 16: 145-156.

Landi L., Isidoro N., Riolo P. 2013. Natural phytoplasma infection of four phloem-feeding Auchenorrhyncha across vineyard agroecosystems in central-eastern Italy. Journal of Economic Entomology 106 (2): 604-613.

Lee I.M., Davis R.E., Chen T.-A., Chiykowski L.N., Fletcher J., Hiruki C., Schaff D.A. 1992. A genotype-based system for identification and classification of mycoplasmalike organisms (MLOs) in the aster yellows MLO strain cluster. Phytopathology 82: 977-986.

Lee I.M., Davis R.E., Gundersen-Rindal D.E. 2000. Phytoplasma: Phytopathogenic mollicutes. Annual Review of Microbiology 54: 221-255.

Lee I.M., Gundersen-Rindal D.E., Davis R.E., Bottner K.D., Marcone C., Seemuller E. 2004. 'Candidatus Phytoplasma asteris', a novel phytoplasma taxon associated with aster yellows and related diseases. International Journal of Systemic and Evolutionary Microbiology 54: 1037-1048.

Lee I.M., Hammond R.W., Davis R.E., Gundersen D.E. 1993. Universal amplification and analysis of pathogen 16S rDNA for classification and identification of mycoplasmalike organism. Phytopathology 83: 834-842.

Lee I.M., Martini M., Bottner K.D., Dane R.A., Black M.C., Troxclair N. 2003. Ecological implications from a molecular analysis of phytoplasmas involved in an aster yellows epidemic in various crops in Texas. Phytopathology 93: 1368-1377.

Lehmann W., Skadow K. 1971. Untersuchungen zur Verbreitung, Ätiologie und Vektorübertragbarkeit der Blütenvergrünung des Rapes. Archiv für Phytopathologie und Pflanzenschutz 7: 323-336.

Maixner M., Ahrens U., Seemuller E. 1995. Detection of the German grapevine yellows (Vergilbungskrankheit) MLO in grapevine, alternative hosts and a vector by a specific PCR procedure. European Journal of Plant Pathology 101: 241-250.

Maramorosch K. 1960. Leafhopper - transmitted plant viruses. Protoplasma 52: 457-466.

McCoy R.E., Caudwell A., Chang C.J., Chen T.A., Chiykowski L.N., Cousin M.T., Dale J.L., de Leeuw G.T.N., Golino D.A., Hackett K.J., Kirkpatrick B.C., Marwitz R., Petzold H., Sinha R.C., Sugiura M., Whitcomb R.F., Yang I.L., Zhu B.M., Seemüller E. 1989. Plant diseases associated with mycoplasma-like organisms. p. 546-563. In: "The Mycoplasmas, Vol. V: Spiroplasmas, Acholeplasmas, and Mycoplasmas of Plants and Arthropods" (R.F. Whitcomb, J.G. Tully, eds.). Academic Press, San Diego, USA, 653 pp.

Musil M. 1975. Tagungsber. Akad. Landwirtsch. - Wiss. DDR, Berlin 134, 171.

Nowacka W. 1982. Skoczki (Homoptera, Auchenorrhyncha) występujące w uprawach zbóż i traw nasiennych na terenie Polski. Roczniki Akademii Rolniczej w Poznaniu 122, 82 ss.

Okuda S., Prince J.P., Davis R.E., Dally E.L., Lee I.-M., Morgen B., Kato S. 1997. Two groups of phytoplasmas from Japan distinguished on the basis of amplification and restriction analysis of 16S rDNA. Plant Disease 81: 301-305.

Olivier C.Y., Séguin-Swartz G., Galka B., Olfert O.O. 2011. Aster yellows in leafhoppers and field crops in Saskatchewan, Canada, 2001-2008. The Americas Journal of Plant Science and Biotechnology 5 (Special Issue 2): 88-94.

Orsagova H., Brezikova M., Schlesingerova G. 2011. Presence of phytoplasmas in hemipterans in Czech vineyards. Bulletin of Insectology 64: S119-S120.

Ploaie P.G. 1981. Mycoplasma-like organisms and plant diseases in Europe. p. 61-104. In: "Plant Diseases and Vectors: Ecology and Epidemiology" (K. Maramorosch, K.F. Harris, eds.). Academic Press, New York, USA, 368 pp.

Salehi M., Izadpanah K., Siampour M. 2011. Occurrence, molecular characterization and vector transmission of a phytoplasma associated with rapeseed phyllody in Iran. Journal of Phytopathology 159 (2): 100-105.

Schneider B., Seemüller E., Smart C.D., Kirkpatrick B.C. 1995. Phylogenetic classification of plant pathogenic mycoplasmalike organisms or phytoplasmas. p. 369-380. In: "Molecular and Diagnostic Procedures in Mycoplasmalogy" (S. Razin, J.G. Tully, eds.). Academic Press, New York, USA, 466 pp.

Schultz G.A. 1973. Plant resistance to aster yellows. Proceedings North Central Branch Entomological Society of America 28: 93-99.

Sichani F.V., Bahar M., Zirak L. 2014. Characterization of phytoplasmas related to aster yellows group infecting annual plants in Iran, based on the studies of 16S rRNA and $r p$ genes. Journal of Plant Protection Research 54 (1): 1-8.

Tanaka M., Tanina K., Kasuyama S., Usugi T. 2007. Occurrence of rocket larkspur witches' broom caused by “Candidatus Phytoplasma asteris" in Japan. Journal of General Plant Pathology 73 (4): 286-289.

Tsai J.H. 1979. Vector transmission of mycoplasmal agents of plant diseases. p. 265-307. In: "The Mycoplasmas, Vol. III: Plant and Insect Mycoplasmas" (R.E. Whitcomb, J.G. Tully, eds.). Academic Press, New York, USA, 351 pp.

Weintraub P.G., Beanland L. 2006. Insect vectors of phytoplasmas. Annual Review of Entomology 51 (1): 91-111.

Zhang J., Hogenhout S.A., Nault L.R., Hoy C.W., Miller S.A. 2004. Molecular and symptom analyses of phytoplasma strains from lettuce reveal a diverse population. Phytopathology 94 (8): 842-849.

Zwolińska A., Krawczyk K., Klejdysz T., Pospieszny H. 2011a. First report of 'Candidatus Phytoplasma asteris' associated with oilseed rape phyllody in Poland. Plant Disease 95 (11): 1475.

Zwolińska A., Krawczyk K., Maćkowiak-Sochacka A., Kamasa J. 2011b. Identyfikacja fitoplazm porażających rzepak ozimy w Polsce. [Identification of phytoplasma affecting winter oilseed rape in Poland]. Progress in Plant Protection/Postępy w Ochronie Roślin 51 (4): 1659-1662.

Vacke J. 1966. Ochrana Rostlin (Praha) 8: 127. 